\title{
Solar energy for net zero energy buildings - a comparison between solar thermal, PV and photovoltaic-thermal (PV/T) systems
}

Clara Good, Inger Andresen, Anne Grete Hestnes

Department of Architectural Design, History and Technology, Norwegian University of Science and Technology (NTNU), Alfred Getz vei 3, 7491 Trondheim, Norway

\section{Graphical abstract}
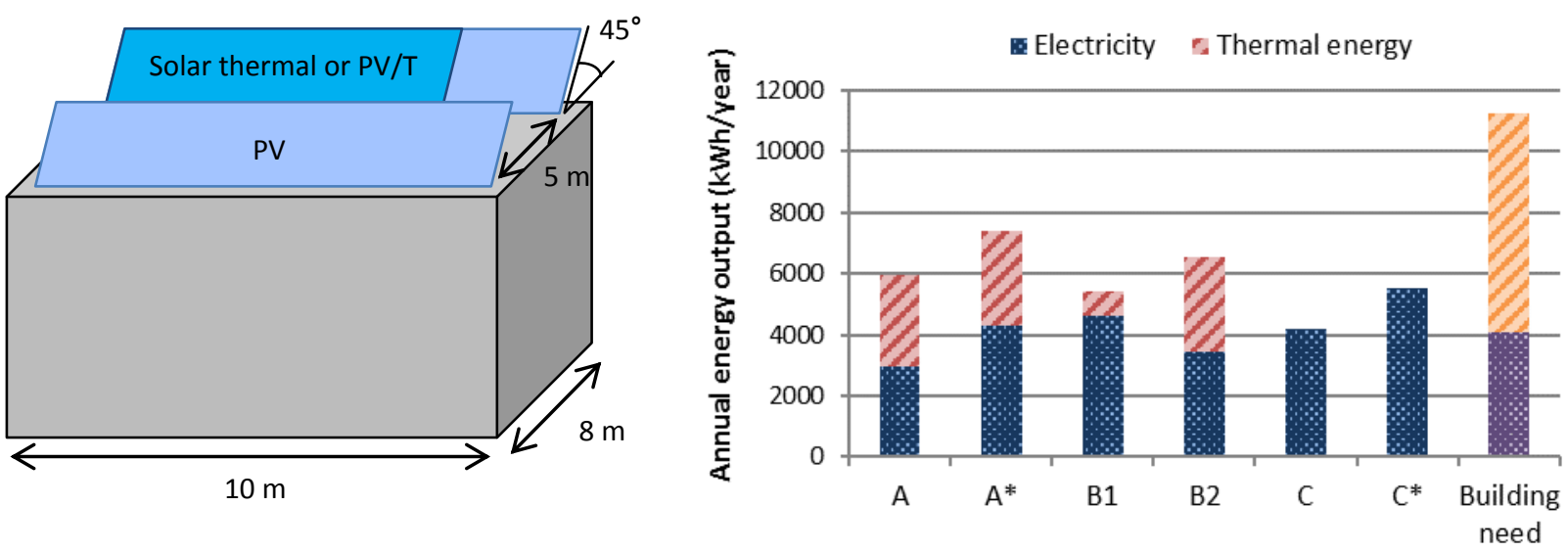

A: PV and solar thermal, $\mathbf{A}^{*}$ : State-of-the-art PV and solar thermal B1: uncovered PV/T, B2: covered PV/T and PV

C: PV, C*: state-of-the-art PV

\begin{abstract}
In a net zero energy building (nZEB), the energy demand from the operation of the building is met by renewable energy generated on site. Buildings require energy both in the form of heat and electricity, and solar energy utilization is important in order to reach a net zero energy balance. In projects with ambitious energy targets or limited available areas for local energy generation, solar thermal and photovoltaic (PV) installations will eventually compete for space on roofs and facades. Hybrid photovoltaic-thermal (PV/T) modules, in which heat and electricity is generated simultaneously, are therefore an interesting technology for building applications, which can potentially lead to a higher total efficiency and lower use of space. This paper describes a comparative simulation study of different solar energy solutions for a Norwegian residential building concept aiming for a net zero energy balance. Separate PV and solar thermal systems are compared to PV/T systems, and the resulting energy balances analyzed. The results show that the building with only high-efficiency PV modules comes closest to reaching a zero energy balance, but that the results depend greatly on the nZEB definition, the boundary conditions and the design of the building's energy system.
\end{abstract}

Keywords: net zero energy building; PV/T; PV; solar thermal

\section{Nomenclature}

\begin{tabular}{|lll}
\hline$Q_{\text {sol }}$ & $\mathrm{kWh}$ & thermal energy from solar energy system \\
$Q_{\text {aux }}$ & $\mathrm{kWh}$ & thermal energy from auxiliary heat source \\
$E_{\text {sol }}$ & $\mathrm{kWh}$ & electricity from solar energy system \\
$S F_{\text {th }}$ & - & thermal solar fraction \\
$S F_{\text {el }}$ & - & electricity-specific solar fraction \\
$E_{\text {delivered }}$ & $\mathrm{kWh}$ & delivered (imported) energy to the building \\
$E_{\text {exported }}$ & $\mathrm{kWh}$ & exported energy from the building
\end{tabular}




\begin{tabular}{|lll|}
\hline$E_{n e t}$ & $\mathrm{kWh}$ & the difference between energy imported to and exported from the building \\
$\beta$ & $\circ$ & tilt angle of modules \\
$\gamma$ & $\circ$ & sun height above horizon \\
$T_{m}$ & $\mathrm{~K}$ & mean collector temperature \\
$T_{a}$ & $\mathrm{~K}$ & ambient temperature \\
$\Delta T$ & $\mathrm{~K}$ & difference between mean collector temperature, $\mathrm{T}_{\mathrm{m}}$, and ambient temperature, $\mathrm{T}_{\mathrm{a}}$ \\
$\eta$ & - & thermal efficiency \\
$\eta_{0}$ & - & thermal zero-loss efficiency \\
\hline
\end{tabular}

\section{Introduction}

Buildings account for around a third of the global energy use and a similar share of the greenhouse gas emissions [1]. Making buildings more energy efficient and sustainable is therefore important in order to reduce global energy demand as well as emissions. In a net zero energy building (nZEB $)^{1}$, the amount of energy required to operate the building is generated by renewable energy sources on or near the building [2]. During a specified period of time, typically a year, the building reaches a net zero energy balance. In its recast of the Energy Performance of Buildings Directive (EPBD), the European Union has directed its member states to ensure that by 2020, all new buildings shall be nearly zero energy buildings [3].

. Active solar energy utilization is one of the main strategies used to provide on-site renewable energy to buildings, which is necessary to reach a zero energy balance. Buildings require energy both in the form of heat and electricity during operation, which can be provided by solar thermal collectors and photovoltaic (PV) modules. In projects with ambitious energy targets or limited available area for installations, solar thermal collectors and PV modules may be competing for the available space on the buildings' roofs and facades. In a hybrid photovoltaic-thermal (PV/T) module, electricity and heat is generated simultaneously. This can lead to a high total efficiency per module and possibly to a reduced use of space compared to separate systems. PV/T is therefore an interesting technology for buildings.

This paper describes a comparative simulation study of solar thermal, PV and PV/T systems, applied to the case of a Norwegian low energy residential building. The goal is to achieve a zero energy balance over a year. The energy yield of the different systems are analyzed and compared, and the building energy balance is calculated.

\subsection{Hybrid photovoltaic-thermal (PV/T) modules}

PV/T technology has so far not had a commercial breakthrough comparable to that of PV or solar thermal, but interest in the technology is increasing, especially in connection to low or zero energy buildings [4]. The market for PV/T has increased in the past decade, and a number of solar energy manufacturers now also produce PV/T modules. Some manufacturers even specialize in PV/T technology. A number of different PV/T technologies are available, for example based on the type of heat transfer medium (air or liquid), the configuration of the glazing, and the PV technology used (see for example $[4,5]$ ).

PV modules convert only around $10-20 \%$ of the radiation to electricity, while the rest is reflected or dissipated as heat in the module. The basic idea behind the PV/T technology is to utilize more of the incoming solar radiation by also harvesting the waste heat from PV modules. Since PV cell efficiency typically decreases with increased cell temperature, removing the waste heat can also lead to an increased electricity output. An additional benefit of PV/T modules for building use is that architectural uniformity can be achieved between the thermal and electric installations.

\footnotetext{
${ }^{1}$ Abbreviations

nZEB: net zero energy building (can also refer to net zero emission building), EPBD: Energy Performance of Buildings Directive, ZEB Centre: The Research Centre for Zero Emission Buildings (www.zeb.no), DHW: domestic hot water, HVAC: heating, ventilation and air conditioning, STC: standard test conditions, $\mathrm{kW}_{\mathrm{p}}$ : kilowatt peak, SPF: seasonal performance factor.
} 


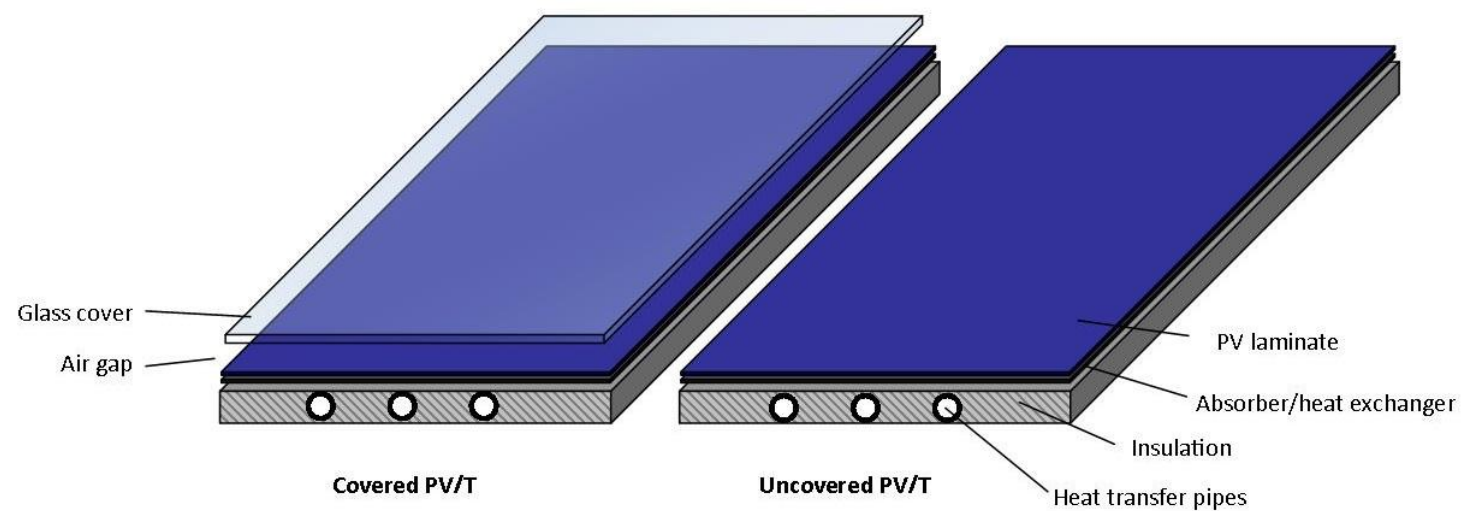

Figure 1. A schematic drawing of a covered (left) and uncovered (right) flat plat PV/T module. Note that the PV laminate also usually includes a cover for structural stability.

A number of PV/T technologies are available, but this study focuses only on flat plate PV/T modules with liquid heat transfer medium. For this type, a basic distinction can be made between covered and uncovered modules (sometimes called glazed and unglazed) [6]. The difference is illustrated in Figure 1. Simply put, an uncovered $\mathrm{PV} / \mathrm{T}$ module is a PV module with cooling. It produces an equal or larger amount of electricity than a regular PV module, and in addition some low-temperature heat. Both types of modules generally include some type of cover for structural stability, but covered PV/T modules have an additional, suspended glazing to prevent heat loss through convection. A covered PV/T module is similar to a solar thermal collector with added PV cells, and has a higher thermal output than an uncovered PV/T module. Adam, et al. [7] performed a market survey of PV/T products available in Germany. This has been used to find products for this study. A large majority of the available products were found to be uncovered collectors (30 out of 41 producers).

\subsection{Zero energy buildings}

There are several different definitions of a net zero energy building (nZEB). In general, an nZEB can be defined as a building that reaches a net zero energy balance over a specified time period, typically a year. The EU targets set out in the EPBD describes a nearly zero energy building as a building with a very high energy performance where "the nearly zero or very low amount of energy required should be covered to a very significant extent by energy from renewable sources, including energy from renewable sources produced on-site or nearby" [3].

In addition, the zero energy balance can be calculated in different ways, depending among other things on the system boundary and weighting factors for the different energy sources that are used [2]. The balance may include the energy used for heating ventilation and air conditioning (HVAC), lighting, and use of electrical equipment. In more ambitious definitions, the balance may also include the energy used in the production of materials, as well as the construction and subsequent dismantling of the building itself. The amount of energy that should be generated on site to reach the zero energy balance therefore depends on the nZEB definition. A proposal for a consistent nZEB definition was presented by Sartori et al [8]. The system boundary used in the case presented here is the building itself, and the annual energy import/export balance is used. That is, the balance is calculated between energy delivered, or imported, to the building $\left(E_{\text {delivered }}\right)$ and the energy exported from the building $\left(E_{\text {exported }}\right)$. The solar energy installations on the roof are considered to be inside the system boundary. Based on [8], the energy balance is then calculated according to equation ( 1 ). The balance in this case is calculated with total annual values. A net zero energy balance is reached if $E_{n e t}(\mathrm{kWh})$ is zero.

$E_{\text {net }}=\left|E_{\text {exported }}\right|-\left|E_{\text {delivered }}\right|$

To reach a net zero energy balance, the first priority should be to decrease the need for delivered energy, and then to meet the remaining demand with on-site renewable energy sources [9]. The delivered energy could include electricity, biomass, district heating, or other energy carriers. The exported energy is in general only electricity, but it could in some cases also include heat, for example to a disctrict heating network. Weighting factors are used to compare energy from different sources in the same equation. According to EN 15503[10], the 
weighing factors can be primary energy, carbon dioxide emissions, or factors determined at national level. A policy rating, imposed to penalise or favour some energy carriers is also mentioned as a possibility. The factors for delivered and exported energy of the same energy carrier can be different or equal (symmetric weighting).

The Research Centre on Zero Emission Buildings (the ZEB Centre, www.zeb.no) in Trondheim, Norway, has defined four different ambition levels for net zero emission buildings. This can be transferred also to net zero energy buildings. The ambiton levels, as well as a complete definition framework, is further described in [11]. In the case presented here, the ambition is to reach nZEB-O, which means that the energy need for operation of the building is considered in the energy balance calclation. The energy demand of equipment, such as computers and lighting, is included, but standardized values are used. Energy demand for materials, construction and demolition is excluded.

\subsection{Solar fraction}

In addition to $E_{\text {net }}$, it is interesting to know the solar fraction, i.e. how much of the heat and electricity that is met by solar energy. The thermal solar fraction $\left(S F_{t h}\right)$ is calculated according equation ( 2$)$, where $Q_{s o l}(\mathrm{kWh})$ is the thermal energy from the solar energy system, and $Q_{a u x}(\mathrm{kWh})$ is the thermal energy from the auxiliary energy source. The solar fraction can be calculated in slightly different ways, depending on how the system losses are allocated. The calculation used here divides the losses between the solar and auxiliary systems.

$S F_{\text {th }}=\frac{Q_{\text {sol }}}{Q_{\text {sol }}+Q_{\text {aux }}}$

The thermal solar fraction is commonly used in solar thermal calculations, but here we have also chosen to define a corresponding electricity-specific solar fraction $\left(S F_{e l}\right)$, calculated according to equation ( 3 ), where $E_{\text {sol }}$ $(\mathrm{kWh})$ is the electricity from the solar energy system, $E_{\text {need }}(\mathrm{kWh})$ is the electricity-specific energy demand of the building.

$S F_{\text {el }}=\frac{E_{\text {gol }}}{E_{\text {negd }}}$

Since the building model used in this study has a heat pump as auxiliary energy source, the total electricity demand also includes electricity for heating. This has not been included in $E_{\text {need, }}$ which encompasses only electricity-specific energy use, i.e. energy need that cannot be covered by another energy source than electricity, such as use of electric equipment or lighting. The total electric solar fraction, including electricity for heating, is the ratio $E_{\text {exported }} / E_{\text {delivered }}$ shown in Table 4.

\section{Background}

\subsection{ZEB residential concept model}

The building model (Figure 2) used in the simulations is based on a concept building model developed at the ZEB Centre. It was created in order to have a simple and realistic building as the basis for various building performance studies. The concept model is designed based on current state-of-the-art in building technology, and is designed to fulfil the requirements of the Norwegian passive house standard [12]. The material use, embodied energy and emissions, design of a HVAC system, technical details and energy performance is well documented and is presented in [13]. The model is therefore well suited to be used as a basis for the solar energy system analysis. 


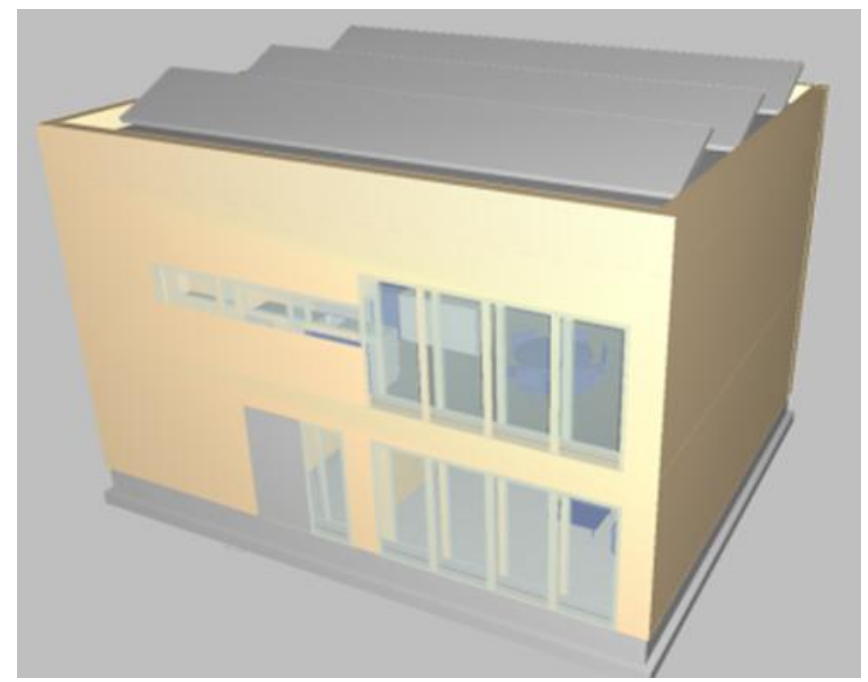

Figure 2. The ZEB concept model of a single family residential building, from Houlihan Wiberg, et al. [13]. The three rectangles on the roof indicate the location of the PV system (note that only two rows are used in this analysis).

The building model is a two-storey residential building with $160 \mathrm{~m}^{2}$ heated floor area. It is located in Oslo in Southern Norway $\left(59.9^{\circ} \mathrm{N}, 10.6^{\circ}\right.$ ), which has an annual average temperature of $6.3^{\circ} \mathrm{C}$. The annual energy demand of the building is shown in Table 1, as determined by Houlihan Wiberg, et al. [13]. The energy demand for domestic hot water (DHW) and electricity is specified in accordance with standard values from the Norwegian standard NS 3031 [14], as are the internal heat gains from people and equipment.

Table 1. The energy demand of the ZEB concept building.

\begin{tabular}{lll}
\hline Energy demand & $\mathbf{k W h} / \mathbf{y e a r}$ & $\mathbf{k W h} / \mathbf{m}^{\mathbf{2}}$ year \\
\hline Space heating & 3349 & 20.9 \\
\hline Domestic hot water & 3811 & 23.8 \\
\hline Electricity & 4074 & 25.5 \\
\hline Total & 11234 & 70.2 \\
\hline
\end{tabular}

The monthly space heating need $\left(\mathrm{kWh} / \mathrm{m}^{2}\right)$ is shown in Figure 3, together with the solar irradiation for Oslo on a surface oriented for maximum annual solar irradiation ( $45^{\circ}$ tilt and south-facing) and a vertical surface, such as a façade. The largest fraction of the solar radiation is available in the summer when there is no space heating need. However, there is still a heating demand during spring and autumn, which coincides with a significant part of the irradiation. 


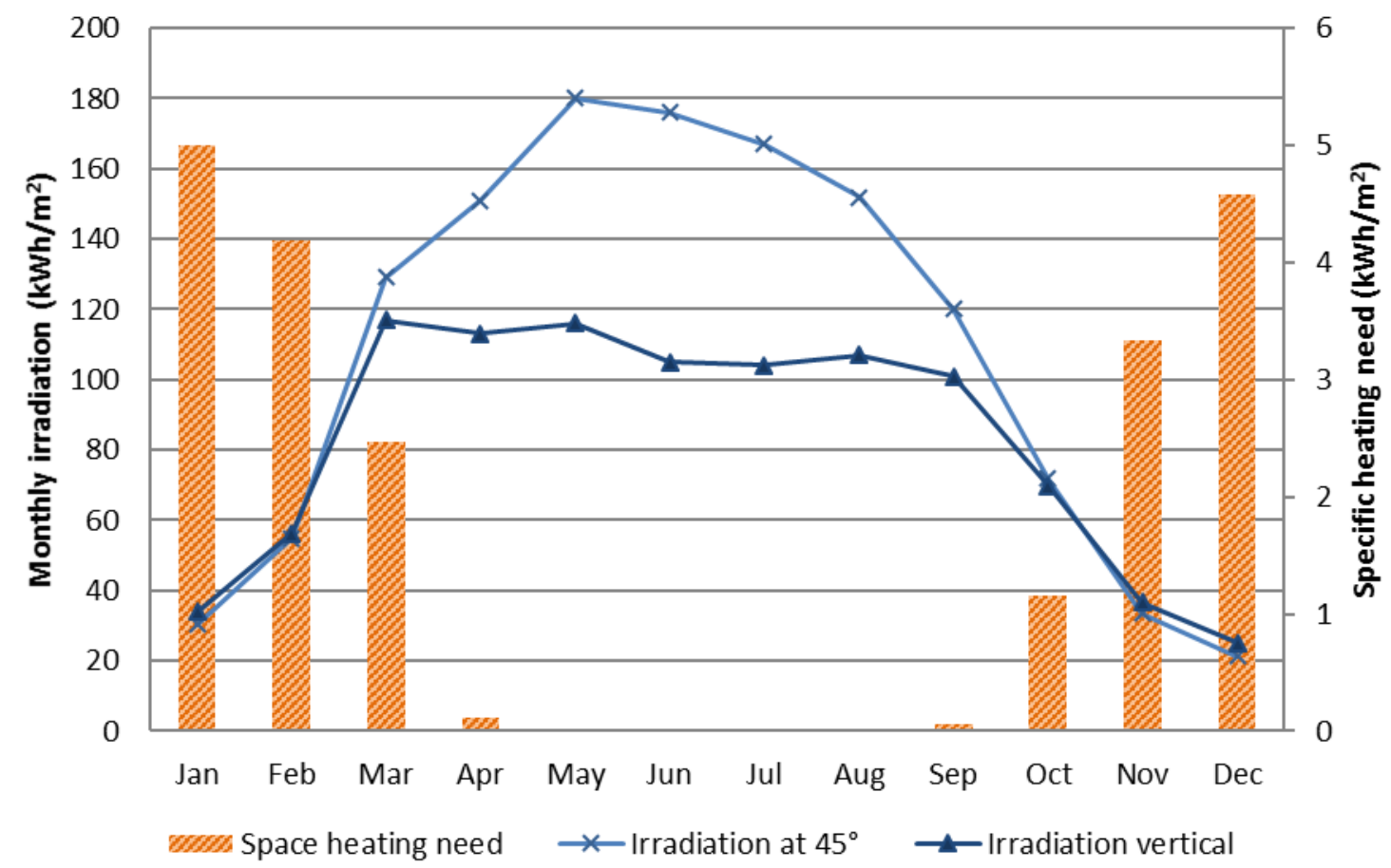

Figure 3. Monthly irradiation on an optimally inclined surface $\left(45^{\circ}\right.$ tilt $)$ and a vertical surface is shown on the left axis, together with the specific heating need of the building $(\mathrm{kWh} / \mathrm{m} 2$ heated floor area) on the right axis, as determined by $\mathrm{Houlihan}$ Wiberg, et al. [13]. Irradiation data from PVGIS [15].

\subsection{Building energy system}

The building has an HVAC system with mechanical ventilation and heat recovery, which is thoroughly described in [13]. A schematic drawing of the thermal part of the building energy system is shown in Figure 4. The heating is distributed by a low-temperature hydronic system with floor heating (inlet/return temperature $30 / 25^{\circ} \mathrm{C}$ ) and radiators (inlet/return temperature $40 / 30^{\circ} \mathrm{C}$ ). The central part of the heating system is a well-insulated water storage tank, which stores energy and buffers between heat sources and loads at different temperatures. A tankin-tank system is used for the tap water. With a store temperature of $55^{\circ} \mathrm{C}$ and a temperature at the tap of $45^{\circ} \mathrm{C}$, the stand-by volume that needs to be available at all times is estimated to around 1001 . This volume is kept the same in all the simulated systems. 


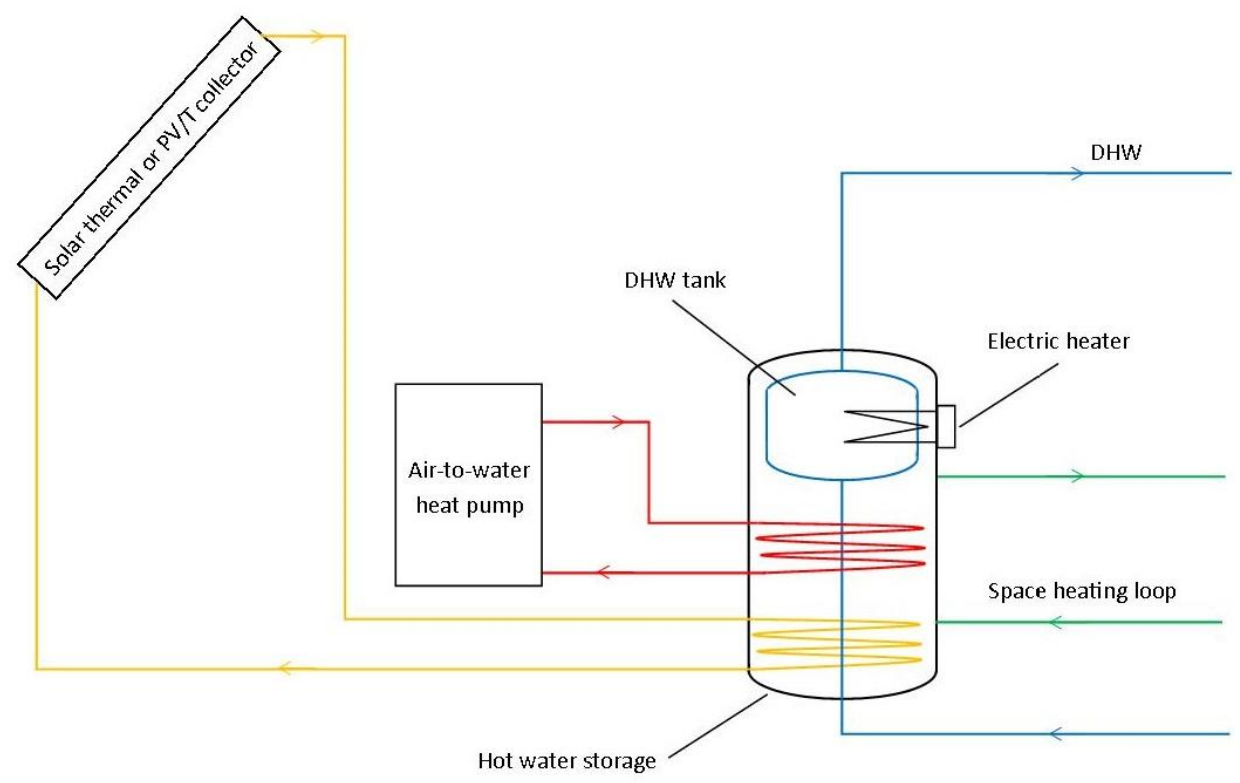

Figure 4. A schematic drawing of the thermal part of the building energy system (not including PV system).

The solar thermal system with glycol/water mix as heat transfer medium is connected to the tank by an internal heat exchanger. The space heating loops are directly connected to the tank. The control strategy prioritizes the heating from the solar energy systems. When necessary, auxiliary thermal energy is provided by an air to water heat pump $(7 \mathrm{~kW})$. The heat pump delivers a temperature of up to $55^{\circ} \mathrm{C}$, depending on the outdoor temperature, which is sufficient for the hot tap water preparation. An electric heater in the upper part of the tank is used to prevent legionella growth. The system is described in detail in [16].The PV systems (not shown in the figure) and the electric part of the PV/T systems are grid-connected, using standard DC/AC inverters. No module level power optimizers or batteries are used in the system.

\section{Method}

\subsection{Comparative study}

Three versions of the building model (A, B and C) are simulated to study the performance of different solar energy systems for zero energy buildings. Building A has a system with a combination of solar thermal collectors and PV modules and represents the original design of the building model. Building B has a system of $\mathrm{PV} / \mathrm{T}$ and PV modules, and building $\mathrm{C}$ has only PV modules installed. The hydronic heating system is the same in all versions of the building, except for the dimensions of the tank and piping.

The simulations are performed in the program Polysun, which is a dynamic simulation tool for solar energy solutions including solar thermal, $\mathrm{PV}$ and $\mathrm{PV} / \mathrm{T}$, as well as for various hydronic systems, such as heat pumps and district heating system [17]. Meteonorm weather data is used in the simulation [18]. The modelling of the systems for this study was based on a combination of in-program models and data from manufacturers. The energy output, thermal and electric solar fraction, and energy balance are calculated for each of the systems.

\subsection{Objective and boundary conditions}

Thermal energy and electricity have different uses in buildings and thereby different value. The objective and boundary conditions will therefore have a significant impact on the results and the conclusions that can be drawn. A review of methodologies to evaluate PV/T systems in comparison with PV and solar thermal collectors were outlined by Delisle and Kummert [19]. They found that a number of methodologies were used by different authors, such as combined energy or exergy efficiency, combined primary energy saving efficiency, equivalent area or economic factors. In this study we have chosen to use the available area as the boundary condition, but the comparison is based on the calculated import/export energy balance. 
The objective is to investigate which of the three building alternatives comes closest to achieving a net zero energy balance. The ambition level is ZEB-O according to the guidelines developed by the ZEB Centre, which were outlined in the section 1.2 and are further described in [11]. Since the auxiliary heating in this case is provided by a heat pump, electricity is the only form of delivered energy to the building. The exported energy is likewise only electricity from the PV or PV/T systems. As there is only one energy carrier being imported and exported, and the purpose is to compare the buildings against each other, no weighting factors are used.

It is assumed that there are no restrictions on the electricity exchange with the grid, and electricity generated by the solar energy systems is therefore in this analysis considered useful at all times. In reality, electricity will be valued differently at different times. Using as much as possible of the self-generated electricity directly in the building can therefore be desirable, but this will not be further considered here. The thermal energy from the solar collectors is only useful if it can be used or stored. Once the storage tank has reached its upper temperature limit, additional thermal output cannot be used.

Only the roof area $(8 \mathrm{~m} \mathrm{x} 10 \mathrm{~m})$ is considered to be available for the solar installations. Installing solar energy systems on flat roofs, especially in northern regions, requires that row-to-row shading is considered, but it is assumed here that there are no surrounding buildings or structures shading the installations. The required distance $d(\mathrm{~m})$ between rows can be calculated according to equation ( 4 ), where $b(\mathrm{~m})$ is the module height, $\beta$ $\left({ }^{\circ}\right)$ is the tilt angle of the modules, and $\gamma\left({ }^{\circ}\right)$ the sun angle, which is the angle between the sun and the horizon. [20].

$d=b \cdot \frac{\sin \left(180^{\circ}-\beta-\gamma\right)}{\sin (\gamma)}$

The optimal orientation in Oslo is around $45^{\circ}$ tilt and south-facing. The lowest sun angle in Oslo is around $7^{\circ}$ (beginning of January, note that the sun angle refers to the sun height at noon), meaning that the modules would have to be spaced around $10 \mathrm{~m}$ to avoid shading completely. Since the roof is only $8 \mathrm{~m}$ wide, this means that only one row would fit on the roof. As $2-8 \%$ of the solar radiation is received during the winter months, it was assumed that some shading could be tolerated in order to fit two rows on the roof. Accounting for the length of the modules themselves, the longest spacing possible is $7 \mathrm{~m}$, which means that the modules are unshaded from the beginning of February. A schematic drawing of the installations is shown in Figure 5. The shading analysis is performed internally in the simulation program. The row-to-row shading is accounted for in a somewhat simplified manner using a composite horizon line. In addition, shading of PV modules is added in the roof layout in the program.

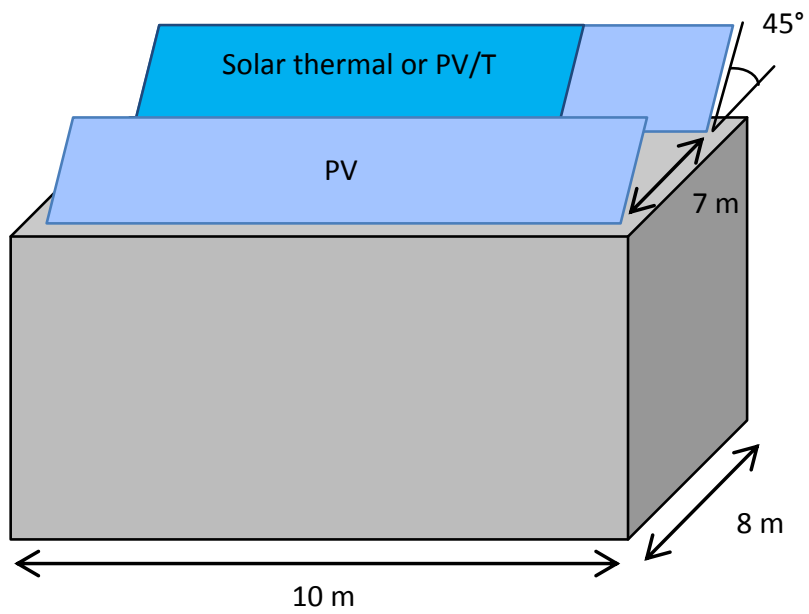

Figure 5. A schematic drawing (not to scale) of the solar installations on the roof. The back row includes solar thermal in building $\mathrm{A}, \mathrm{PV} / \mathrm{T}$ in building $\mathrm{B}$, and only PV in building $\mathrm{C}$. 
Since geometric dimensions from market-available modules are used in this study, the active area in each of the different systems is not exactly the same. A generic spacing of $5 \mathrm{~cm}$ between modules is used. As the output of PV modules is more dramatically influenced by shading than that of solar thermal collectors, the latter are placed in the back row. Note that the back row in building $\mathrm{C}$ and $\mathrm{C}^{*}$ includes only PV modules.

The tilt angle of $45^{\circ}$ is close to optimal for PV modules, but solar thermal collectors are typically installed at a somewhat steeper angle or even on the façade. This slightly increases the yield at times when heating is needed, i.e. spring and autumn when the sun is low. Since the modules analyzed here include PV, solar thermal and combinations of the two, all modules are installed at the same tilt angle to simplify the comparison.

The modules could also have been mounted at a lower tilt angle and with less spacing, which would increase the installed power on the roof but reduce the specific yield $\left(\mathrm{kWh} / \mathrm{kW}_{\mathrm{p}}\right)$. If the tilt angle was reduced to around $10^{\circ}$, another row of modules could have been installed with the same level of shading. The consequences of different installation designs are studied in more detail in Good, et al. [21]. Other installations options, such as facades and different tilt angles, will be included in further studies.

\subsection{Selection of solar modules}

An overview of characteristics of the selected modules is given in Error! Reference source not found.. The solar thermal collectors and PV modules used in the simulation are selected to represent average (STavg and PVavg) to high-end (SThigh and PVhigh) products available on the market, in terms of performance.

Table 2. Characteristics of the solar thermal (ST), PV and PV/T modules used in the simulations.

\begin{tabular}{llllll}
\hline Module & Technology & Gross area $\left[\mathbf{m}^{\mathbf{2}]}\right.$ & $\begin{array}{l}\text { Electric efficiency } \\
\text { at STC [\%] }\end{array}$ & $\left.\begin{array}{l}\text { Rated electric } \\
\text { power [kW }\end{array}\right]$ & $\begin{array}{l}\text { Thermal zero-loss } \\
\text { efficiency } \boldsymbol{\eta}_{\mathbf{0}}[\boldsymbol{\%}]\end{array}$ \\
\hline STavg & Flat plate & 2.00 & - & - & 80 \\
\hline SThigh & Flat plate & 2.00 & - & - & 85 \\
\hline PVavg & Poly-Si & 1.65 & 15.8 & 260 & - \\
\hline PVhigh & Mono-Si & 1.64 & 20.3 & 333 & - \\
\hline PV/Ta & $\begin{array}{l}\text { Mono-Si, uncovered, } \\
\text { uninsulated }\end{array}$ & 1.64 & 17.4 & 285 & 61.4 \\
\hline PV/Tb & $\begin{array}{l}\text { Poly-Si, covered, } \\
\text { insulated }\end{array}$ & 2.26 & 12.0 & 240 & 71.5 \\
\hline
\end{tabular}

The market for PV/T modules is still relatively small compared to that of solar thermal and PV. There is also still a lack of regulations regarding testing and certification of PV/T modules, but since 2013 it is possible to certify modules according to Solar Keymark [22]. According to the certification guidelines, the thermal zero-loss efficiency $\left(\eta_{0}\right)$ should be measured with the PV cells working at their maximum power point. In addition, since the performance of a PV/T module depends both on the thermal and electric characteristics, it is difficult to find a module that represents a market average. In an attempt to account for these differences, two different PV/T modules were used in the simulations: an uncovered PV/T module with good electric performance (PV/Ta), and a covered PV/T module with good thermal performance (PV/Tb). Both of these modules are selected from the upper market range.

\subsection{Solar energy system design}

The main parameters and system dimensions used in the simulations of buildings A, B and C are shown in Error! Reference source not found.. The building versions with high efficiency solar thermal collectors and PV modules are denoted $\mathrm{A}^{*}$ and $\mathrm{C}^{*}$. 
Table 3. The main parameters of the simulated system variants.

\begin{tabular}{lllll}
\hline System & Description & $\begin{array}{l}\text { Installed area } \\
\text { ST/PVT/PV }\left[\mathbf{m}^{\mathbf{2}}\right]\end{array}$ & $\begin{array}{l}\text { Rated electric power } \\
{\left[\mathbf{k W} \mathbf{W}_{\mathbf{p}}\right]}\end{array}$ & $\begin{array}{l}\text { Tank volume } \\
{[\mathbf{l}]}\end{array}$ \\
\hline $\mathrm{A}$ & STavg and PVavg & $10 / 0 / 21$ & 3.4 & 1300 \\
\hline $\mathrm{A}^{*}$ & SThigh and PVhigh & $8 / 0 / 23$ & 4.7 & 1300 \\
\hline $\mathrm{B} 1$ & Only PV/Ta & $0 / 30 / 0$ & 5.1 & 1800 \\
\hline $\mathrm{B} 2$ & $\mathrm{PV} / \mathrm{Tb}$ and PVavg & $0 / 16 / 17$ & 4.3 & 1000 \\
\hline $\mathrm{C}$ & Only PVavg & $0 / 0 / 30$ & 4.7 & 300 \\
\hline $\mathrm{C}^{*}$ & Only PVhigh & $0 / 0 / 30$ & 6.0 & 300 \\
\hline
\end{tabular}

The dimensioning of the system for building A is based on the solar thermal system. In accordance with common design guidelines for Northern European regions, the solar thermal system is designed to most of the thermal energy demand during the summer months (here defined as May to August), when the heat demand is only that for DHW preparation. The area of solar collectors required to do this is slightly smaller with the high efficiency modules, which is why the collector area for building $\mathrm{C}^{*}$ is smaller than for building $\mathrm{C}$.

Since covered and uncovered PV/T modules have different output profiles, two versions of building B are evaluated: B1 with uncovered PV/T modules and B2 with covered PV/T modules.

Simulations of B1 with different ratio between the PV/Ta and PVavg module areas showed that $E_{\text {net }}$ increased with increasing PV/T area. For building B1, uncovered PV/T modules were therefore used on the whole roof area, minimizing $E_{\text {net }}$. Since the thermal output of the uncovered modules is relatively low, it was not possible to reach high thermal solar fractions with this technology. It was also found that a tank size of around $60 \mathrm{l} / \mathrm{m}^{2}$ collector was suitable for a larger PV/Ta system and a slightly higher tank volume to area ratio for smaller systems.

For building B2, the same design strategy as for solar thermal (building A) was used, i.e. that the PV/T system was sized to meet most of the energy demand during summer, and the rest of the roof area was covered with PV modules. Simulations showed that it requires a PV/T area of around $16 \mathrm{~m}^{2}$ (7 modules) in order to reach the same thermal coverage as for building A. The rest of the available area was used for PV modules.

In building $\mathrm{C}$, all available roof space has been used for a PV installation. This building includes the same hydronic heating system as buildings $\mathrm{A}$ and $\mathrm{B}$, but without the solar thermal contribution. The tank size was decreased to only work as a buffer for the heat pump. The stand-by volume for the DHW was kept the same as in the other systems.

\section{Results}

The buildings $\mathrm{A}, \mathrm{B}$ and $\mathrm{C}$ were simulated according to the conditions described in the previous sections. The annual thermal and electricity output of the systems are shown in Figure 6, measured in kilowatt-hours. No weighing factors between thermal energy and electricity are taken into account in this figure. The systems with the highest thermal energy output (A, B2 and $\mathrm{A}^{*}$ ) are also the systems with the highest total output with this way of evaluation. 


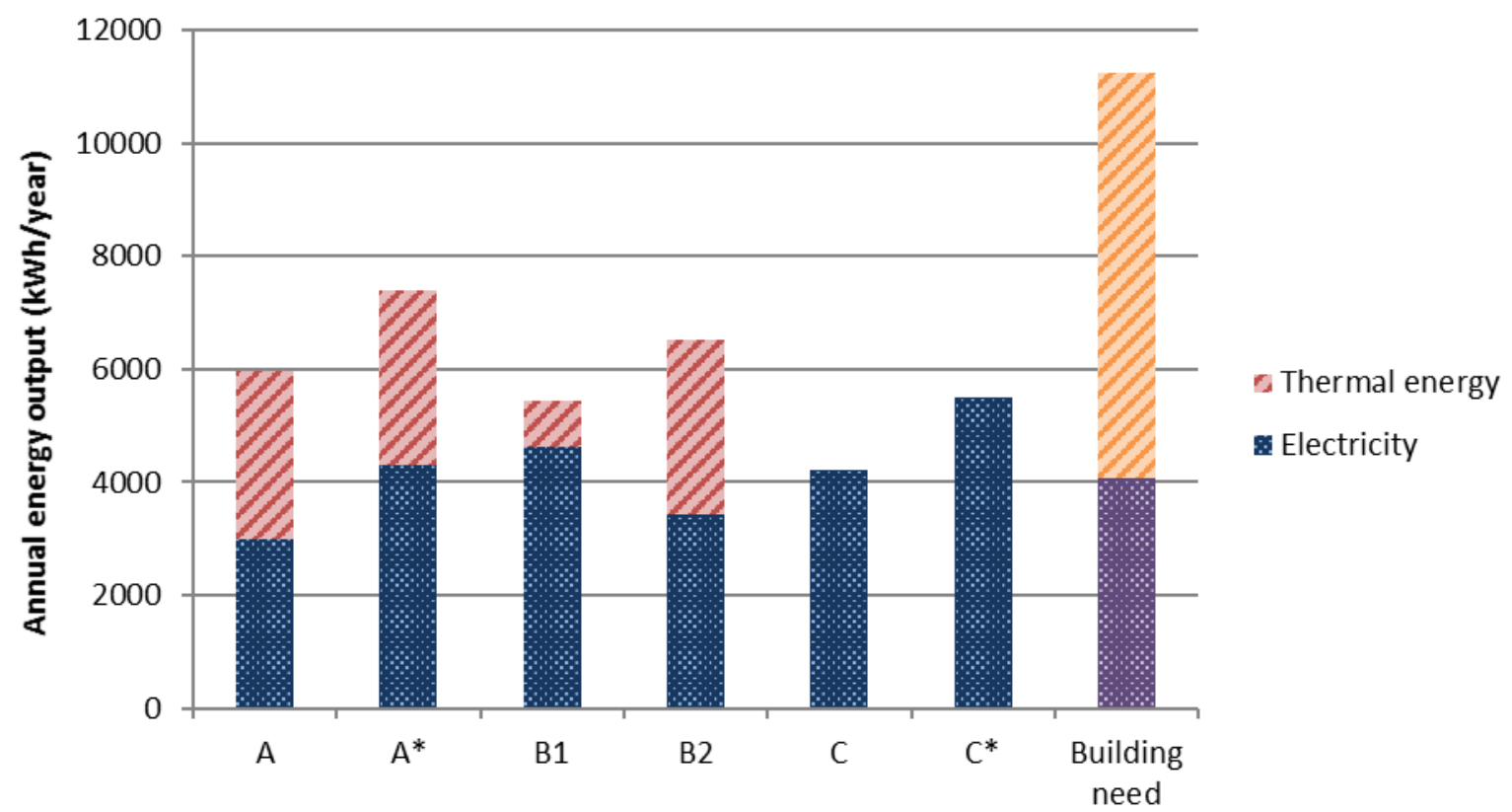

Figure 6. The annual thermal and electric output of the different systems. The rightmost column shows the simulated net thermal and electric energy need of the building. No weighting between thermal energy and electricity is taken into account in this figure.

The thermal and electric solar fractions are shown in Table 4, together with the import/export energy balance calculations. None of the systems reach a net zero energy balance $\left(E_{n e t}>0\right)$. A higher number means a higher coverage by on-site energy (a building with $E_{\text {net }}=0$ would have $100 \%$ coverage). The ratio $E_{\text {exported }} / E_{\text {delivered }}$ in the third column in Table 4 shows the percentage of the delivered energy that can be covered by exported energy, i.e. how close the building is to reaching a zero energy balance. As mentioned in section 1.3, this can in this case also be interpreted as the total electric solar fraction.

Table 4. The thermal and electric solar fractions, the ratio between exported and delivered energy, the ratio $E_{\text {exported }} / \mathbf{E}_{\text {delivered }}$, and the net delivered energy $E_{n e t}$ is shown.

\begin{tabular}{lllll}
\hline System & $\mathbf{S F}_{\text {th }}[\mathbf{\%}]$ & $\mathbf{S F}_{\text {el }}[\boldsymbol{\%}]$ & $\mathbf{E}_{\text {exported }} \mathbf{E}_{\text {delivered }}[\mathbf{\%}]$ & $\mathbf{E}_{\text {net }}[\mathbf{k W h}]$ \\
\hline $\mathrm{A}$ & 33 & 73 & 44 & -3796 \\
\hline $\mathrm{A}^{*}$ & 33 & 105 & 64 & -2446 \\
\hline $\mathrm{B} 1$ & 9 & 113 & 62 & -2822 \\
\hline $\mathrm{B} 2$ & 34 & 84 & 51 & -3300 \\
\hline $\mathrm{C}$ & 0 & 103 & 56 & -3353 \\
\hline $\mathrm{C}^{*}$ & 0 & 134 & 73 & -2086 \\
\hline
\end{tabular}

The system that is closest to reaching a balance is system $\mathrm{C}^{*}$, with only state-of-the-art PV modules and no thermal collectors. This system meets $73 \%$ of the delivered electricity with exported solar electricity. The stateof-the-art system with solar thermal and PV (A*) has the highest solar fraction, and is the second closest to reach a balance, with $64 \%$ of the delivered energy met by on-site electricity. Of the systems with PV/T studied, the uncovered PV/T system in B1 is the closest to a balance, with $62 \%$ of the delivered electricity met by solar generated electricity. Due to the use of a heat pump for auxiliary energy, the systems with high electricity output are favored in this calculation. 
Building $A^{*}$

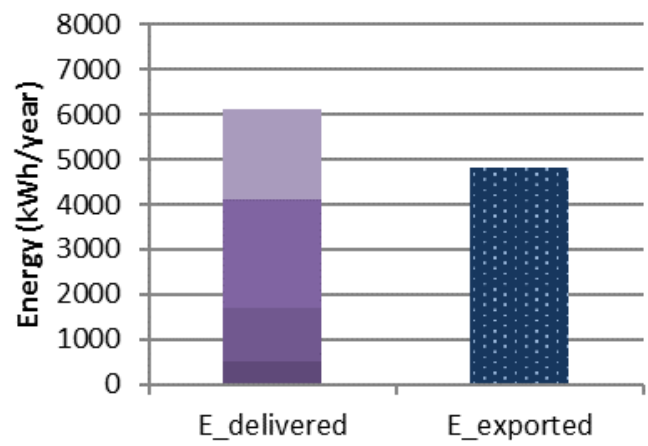

Building $\mathrm{C}^{*}$

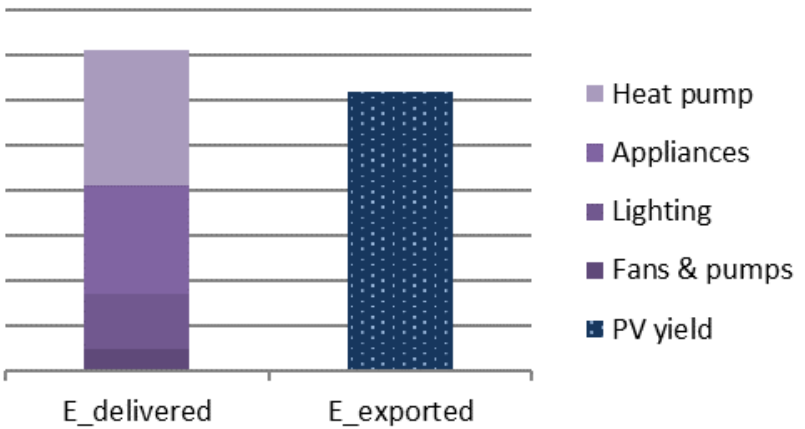

Figure 7. The energy balance of building $A *$ and building $C *$ Even though the amount of energy delivered to building $A *$ is lower than that to building $C^{*}$, the latter is closer to reaching a zero energy balance.

System $C^{*}$ has the highest coverage of on-site energy generation, even though it has the highest value of $E_{\text {delivered }}$, while building $A^{*}$ has the lowest value. The difference between these two buildings is shown in Figure 7.

According to the nZEB definition is used here, building $\mathrm{C}^{*}$ is closer to reaching a zero energy balance since the value of $E_{n e t}$ for this building is smaller.

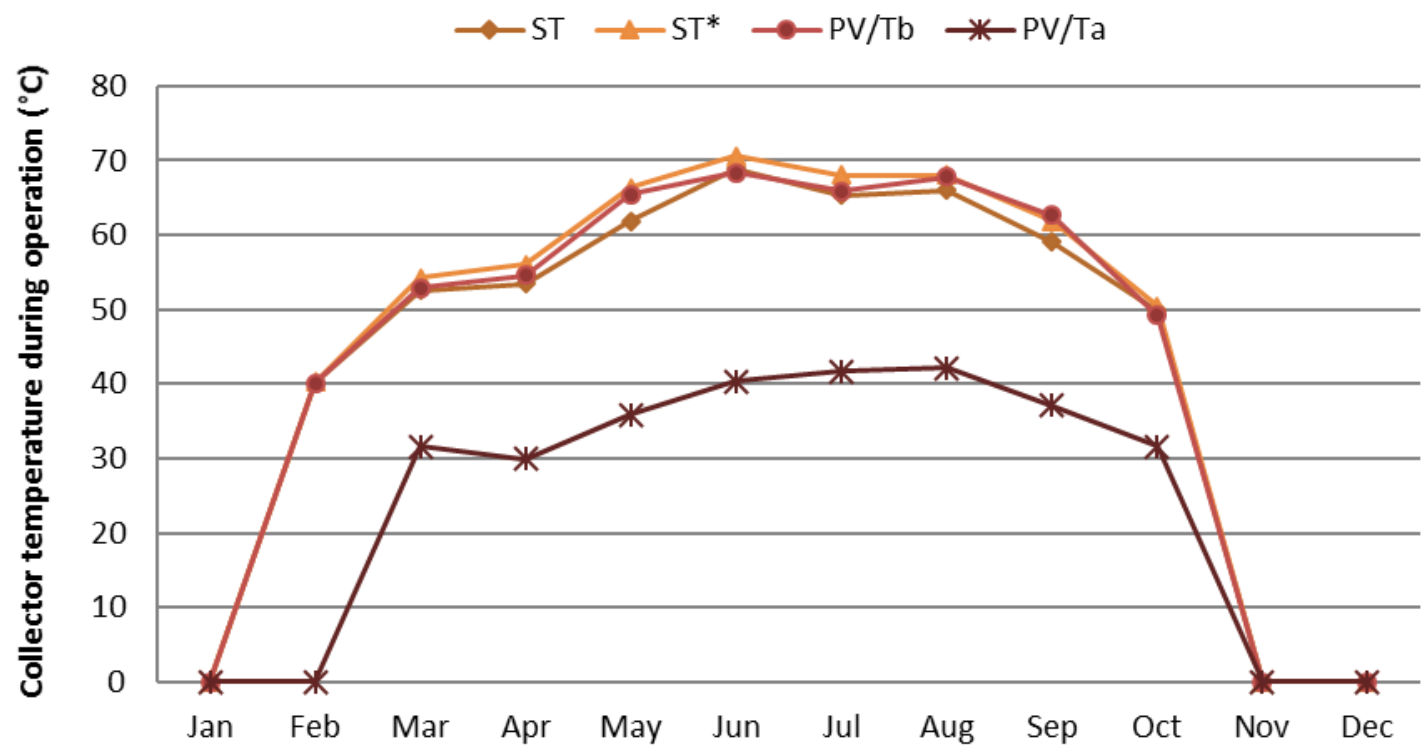

Figure 8. The monthly average collector temperature during operation in the solar thermal collectors (A and A*) and PV/T modules (B1 and B2) during the year, given as monthly averages.

The values for $E_{n e t}$ for the two building versions with PV/T modules, B1 and B2, are relatively similar, but the output profiles are different. The monthly average collector temperatures during operation of the solar thermal collectors and PV/T modules are presented in Figure 8. As expected, the state-of-the-art solar thermal collectors (SThigh) generally have the highest temperature. The uncovered PV/Ta modules have the lowest temperature, and reach only an average operational temperature of $40^{\circ} \mathrm{C}$ during the summer months. During November to February, the temperature reached by the PV/Ta modules cannot be used by the system, compared to November-January for the three other module types 


\section{Discussion}

\subsection{Solar energy and the $n Z E B$ definition}

The results presented here do not give an unambiguous answer to the question of which solar energy system is the best choice for this type of building. Many factors influence the answer, for example how the energy balance is calculated, what the boundary conditions are, and if the goal is to reach the lowest possible energy use or a lowest value of delivered energy, primary energy, greenhouse gas emissions, or other metric.

To reach a zero energy balance, the imported energy should be balanced by the export of locally generated renewable energy. Normally, the only form of energy export that takes place in an nZEB building is that of electricity to the grid (although e.g. thermal export to a district heating network could be possible as well). This means that an electricity source needs to be included in any building where the aim is a net zero energy balance. In this case, the choice of auxiliary heat source is also an important factor, since e.g. the use of a heat pump means that only electricity is imported and exported. This favors systems with a high electricity output in the net energy balance calculations.

It is not uncomplicated to design systems with different technologies in a way that makes a reasonable comparison possible. The systems for building A, A* and B2 were dimensioned to get full solar thermal coverage during the summer. All systems could instead have been dimensioned to maximize $E_{n e t}$. However, the result of such an optimization is that the thermal part of the system (solar collectors or covered PV/T) should be as small as possible, that is, a system of only PV modules. The exception is the system with uncovered PV/T modules, where the thermal output is an addition that is not at the sacrifice of the electric output. The results from this study appear to support the idea that it is more efficient to use PV in combination with heat pumps for residential buildings, than it is to use solar thermal collectors. If the ambition is only to reach a net zero energy balance, the best choice would according to the results presented here be a high efficiency PV system (building $\left.\mathrm{C}^{*}\right)$, even though the thermal solar fraction is zero. However, the building that is second closest to reaching the nZEB criterion is the one with a combination of a state-of-the-art PV system and solar thermal collectors (building $\mathrm{A}^{*}$ ), which has the highest solar thermal fraction.

\subsection{Energy performance of PV/T systems}

The building with only uncovered PV/T modules (building B1) is the third closest to reaching a net zero energy balance. The thermal solar fraction for this building is only $9 \%$, and the output from the PV/T modules during the summer only reaches moderate temperatures. This means that auxiliary heating is necessary for this building also during the summer, which is not the case for the systems with solar thermal collectors

The two PV/T systems analyzed here were based on the system design of building A, where the solar modules and the heat pump are connected in parallel, and the performance could no doubt be improved with further system adjustments. The SPF of the heat pump is a sensitivity factor in the analysis. The seasonal performance factor (SPF) of the heat pump is around 2.3 for the systems with high solar thermal fraction (A, $\mathrm{A}^{*}$ and $\mathrm{B} 2$ ), and 2.5 for the other systems. The SPF is increased since the heat pump is also operational during the summer, when the outdoor temperatures are higher. The same heat pump was used in all the systems and was dimensioned for the winter load, when outdoor temperatures are colder. In particular, the uncovered PV/T system would work better if it was used for preheating, since the temperatures in the collectors are not high enough, even during summer, to provide heating of domestic hot water. In addition to the parallel connection used here, Ille, et al. [23] analyzed systems with PV/T modules and heat pumps in both series and parallel connection. Their studies also included a system with the option of feeding a borehole heat exchanger. With these configurations, the temperature at which the collector loop starts could be lowered and the operation times of the PV/T modules extended. In such a system it may be possible to utilize the very low temperature output during winter to preheat the input to the heat pump. More research is needed to analyze the usefulness of these systems for Northern European conditions.

As Figure 8 shows, there is a large difference in the temperature of the thermal output from the uncovered and the covered PV/T modules. The thermal energy output of the covered PV/T system, as applied in building B2, is similar to that of the solar thermal collectors, although a larger area of PV/T modules are required to reach this 
temperature. Even though the whole available area was used for the installation of uncovered PV/T modules in building B1, temperatures high enough for direct use for DHW preparation were seldom reached The average operational temperature during summer was $40^{\circ} \mathrm{C}$, compared to around $66^{\circ} \mathrm{C}$ for the other module types. Comparing the energy yield and net energy demand of building A and building B2 (Figure 6 and Table 4), there seems to be a benefit from replacing solar thermal collectors with covered PV/T modules.

\subsection{The PV/T market}

This study is based on solar products that are available on the market. The market for PV/T modules is still small, which means that the analysis is probably in favor of the PV and solar thermal technologies, whose markets are larger and more mature. Even though modules from the upper end of the market in terms of efficiency were used here, they are still far behind the efficiencies found in the PV and solar thermal markets. For example, the state-of-the-art PV modules had an efficiency of over 20\%, while the highest electrical conversion efficiency found in a PV/T module was $17.4 \%$. There is also some uncertainty with respect to the performance data of these modules since it is only recently that standards for testing and certification of PV/T modules have been developed. The analysis of the covered PV/T collector is especially uncertain, since there are very few market-available products of this type.

The thermal efficiencies are likewise lower for PV/T modules on the market than for solar thermal collectors, also for the covered ones. The heat loss is also larger from the PV/T modules compared to pure solar thermal collectors. While thermal insulation gives a higher output temperature and thermal output, it reduces the efficiency of the PV cells and also introduces higher demands on the materials used in the modules.

This study is only focused on currently available technology, for PV/T as well as PV and solar thermal. It is difficult to predicting the future for PV/T technology, as it depends on both technological and market developments. Some future research areas have been discussed by Michael, et al. [24], including development of better adhesives, improved lamination methods and the use of nanotechnology. Better certification and testing standards are also important for the PV/T market development [25].

\subsection{Limitations and further work}

The work presented here is based on simulations of one residential passive house with hydronic heating and heat pump, located in a Northern European climate. The results are therefore limited in their validity, and cannot be directly translated to other cases. They can, however, be used to show some general differences between the technologies and to highlight questions for further analysis.

The zero energy balance calculation used here does not include the full life cycle of the building, but is only focuses on energy use during operation. Furthermore, we have used the term 'nZEB' here to mean a zero energy building. Future work will also focus on zero emission buildings. Further work will include analyses of the energy and emissions embodied in the building during the construction phase, as well as replacements and deconstruction

Some aspects in the comparison of the solar technologies are left out of the analysis. The zero energy balance is here calculated on an annual basis. A more detailed analysis should take the monthly, daily or even hourly load match into account, which may change the fractions of delivered and exported energy. Such an analysis could also include measures to increase self-consumption of energy.

Another important factor is of course cost, which is likewise not considered here. The cost of PV modules has plummeted during the last few years and the market is expanding, while PV/T is still an emerging technology and the market is relatively small. Exchanging PV modules for PV/T modules also means that a hydronic system is necessary, which may increase the system complexity. Architectural integration is covered in this paper, but there are clearly benefits of achieving the uniform appearance that can be achieved with PV/T as instead of separate installations of PV and PV/T. 


\section{Conclusions}

Three alternative solar energy systems for a single family building were studied through energy performance simulations. The studied systems were a combination of solar thermal and PV (building A), uncovered PV/T or a combination of covered PV/T and PV (building B), and a system with only PV (building C). The systems are based on commercially available modules and standardized templates.

The objective of the comparative study was to evaluate whether the building with the different installations would reach a net zero energy balance. The goal was to balance the energy demand for operation, according to ambition level ZEB-O, as determined by Dokka, et al. [11]. The auxiliary energy in the system was provided by an air-to-water heat pump, which meant that the import/export energy balance could be calculated only in terms of electricity.

The results show that the system that gets closest to reaching net zero energy balance according to this definition was the system with only high-efficiency PV modules (building $C^{*}$ ), even though the solar thermal fraction in this case was zero. The second closest was the system with high-performance solar thermal collectors and PV modules (building $\mathrm{A}^{*}$ ), which had the highest solar thermal fraction. However, the interpretation of the results depends greatly on the criteria used in the nZEB definition, what boundary conditions are used, and the choice of a heat pump as auxiliary energy source.

The results suggest that covered PV/T could give an increased output compared to solar thermal collectors. The number of collectors with this technology available on the market is, however, very small, which could partly be due to the material challenges involved in producing these types of modules. The system with uncovered PV/T modules holds up well in this comparison where electricity is favored, but the thermal output is small and of low temperature, which means that an auxiliary energy source is necessary also during summer.

\section{Acknowledgements}

This publication was created as part of the Joint Research Centre in Sustainable Energy between Shanghai Jiao Tong University and the Norwegian University of Science and Technology (JRC SJTU-NTNU). The Joint Research Centre is funded by the Research Council of Norway, project number 221657.

This work is based on the results and research of the Norwegian Research Centre for Zero Emission Buildings (www.zeb.no). The authors gratefully acknowledge the support from the Research Council of Norway and several partners through the ZEB Centre.

The authors would like to thank Laurent Georges at the Department of Energy and Process Technology at NTNU for assistance with developing the Polysun model.

\section{References}

[1] International Energy Agency, Transition to Sustainable Buildings - Strategies and Opportunities to 2050, Directorate of Sustainable Energy Policy and Technology (SPT), Paris, France, 2013.

[2] A.J. Marszal, P. Heiselberg, J.S. Bourrelle, E. Musall, K. Voss, I. Sartori, A. Napolitano, Zero Energy Building - A review of definitions and calculation methodologies, Energy and Buildings, 43 (2011) 971-979. [3] European Parliament, Directive 2010/31/EU of the European Parliament and of the Council of 19 May 2010 on the energy performance of buildings, Directive 2010/31/EU, Brussels, 2010.

[4] T.T. Chow, G.N. Tiwari, C. Menezo, Hybrid solar: A review on photovoltaic and thermal power integration, International Journal of Photoenergy, 2012 (2012).

[5] V.V. Tyagi, S.C. Kaushik, S.K. Tyagi, Advancement in solar photovoltaic/thermal (PV/T) hybrid collector technology, Renewable and Sustainable Energy Reviews, 16 (2012) 1383-1398.

[6] N. Aste, C. del Pero, F. Leonforte, Water flat plate PV-thermal collectors: A review, Solar Energy, 102 (2014) 98-115.

[7] M. Adam, H.P. Wirth, R. Radosavljevic, Verbundprojekt: Standardisierung und Normung von multifunktionalen PVT Solarkollektoren (PVT-Norm). Teilvorhaben: PVT-Systemanwendungen und Simulationen, Düsseldorf, 2014. 
[8] I. Sartori, A. Napolitano, K. Voss, Net zero energy buildings: A consistent definition framework, Energy and Buildings, 48 (2012) 220-232.

[9] I. Sartori, I. Graabak, T.H. Dokka, Proposal of a Norwegian ZEB definition: Storylines and Criteria, in: Renewable Energy Conference, Trondheim, 2010.

[10] EN 15603:2008 - Energy performance of buildings - Overall energy use and definition of energy ratings, European Committee for Standardization (CEN), Brussels, Belgium, 2008.

[11] T.H. Dokka, I. Sartori, M. Tyholt, K. Lien, K. Byskov Lindberg, A Norwegian Zero Emission Building Definition, in: Passivhus Norden 2013, Gothenburg, Sweden, 2013.

[12] NS 3700 - Criteria for passive houses and low energy houses - Residential buildings, Standard Norge, Lysaker, 2010.

[13] A. Houlihan Wiberg, L. Georges, T.H. Dokka, M. Haase, B. Time, A.G. Lien, S. Maltha, A net zero emission concept analysis of a single-family house., Energy and Buildings, 74 (2014) 101-110.

[14] NS 3031:2011 - Calculation of energy performance of buildings - Method and data, Standard Norge, Lysaker, 2011.

[15] Institute for Energy - Renewable Energy Unit, Photovoltaic Geographical Information System (PVGIS), European Commission, Joint Research Centre.

[16] T.H. Dokka, A.H. Wiberg, L. Georges, S. Mellegård, B. Time, M. Haase, M. Maltha, A.G. Lien, A zero emission concept analysis of a single family house, The Research Centre on Zero Emission Buildings, Oslo, 2013

[17] Vela Solaris AG, Polysun Simulation Software, Institut für Solartechnik SPF, Rapperswil, 2012.

[18] Meteotest, Meteonorm Database, 2009.

[19] V. Delisle, M. Kummert, A novel approach to compare building-integrated photovoltaics/thermal air collectors to side-by-side PV modules and solar thermal collectors, Solar Energy, 100 (2014) 50-65.

[20] The German Solar Energy Society, Planning and installing photovoltaic systems: a guide for installers, architects and engineers, Earthscan, London, 2013.

[21] C. Good, A. Houlihan Wiberg, T.F. Kristjansdottir, L. Georges, A.G. Hestnes, A comparative study of different PV installations for a Norwegian net zero emission building concept, in: E. Frank, P. Papillon (Eds.) Eurosun 2014, ISES, Aix-les-Bains, France, 2014.

[22] Solar Keymark Network, Specific CEN Keymark Scheme Rules for Solar Thermal Product version 21.00, CEN Certification, 2013.

[23] F. Ille, M. Adam, R. Radosavljevic, H.P. Wirth, Market and simulation analysis of PVT applications for the determination of new PVT test procedures, in: E. Frank, P. Papillon (Eds.) Eurosun 2014, ISES, Aix-les-Bains, France, 2014.

[24] J.J. Michael, I. S, R. Goic, Flat plate solar photovoltaic-thermal (PV/T) systems: A reference guide, Renewable and Sustainable Energy Reviews, 51 (2015) 62-88.

[25] K. Kramer, H. Helmers, The interaction of standards and innovation: Hybrid photovoltaic-thermal collectors, Solar Energy, 98, Part C (2013) 434-439. 